\title{
CORRELATION OF LEADERSHIP BEHAVIOR OF SCHOOL HEADMASTERS AND ORGANIZATIONAL CLIMATE ON TEACHER JOB SATISFACTION AT PUBLIC ELEMENTARY SCHOOLS
}

\author{
Muhammad Yuliansyah \\ University of Islam Kalimantan Muhammad Arsyad Al-banjari, Indonesia \\ m.yuliansyahy@yahoo.com
}

\begin{abstract}
This study found some evidences of a significant relationship between headmaster leadership behavior and organizational climate on teacher work satisfaction. This finding does not contradict with what was written by Qazwini (2008) that climate can affect job satisfaction, which refers to Herzberg's statement which states that there are two factors that affect one's job satisfaction in the organization: the motivator factors and the hygiene factors. There is a positive and significant correlation between headmaster leadership behavior and job satisfaction of teacher of Public Elementary School in Banjarmasin Selatan Subdistrict. Where the positive relationship is expressed with the value of $r=0.495$. There is a positive and significant relationship between school organizational climate and job satisfaction of elementary school teachers in Banjarmasin Selatan Subdistrict. Where this positive relationship is expressed with the value of $r=0.581$. There is a positive and significant correlation between headmaster leadership behavior and organizational climate with job satisfaction of Public elementary school teacher in Banjarmasin Selatan sub-district. Expressed by value $\mathrm{R}=0.675$.
\end{abstract}

Keywords: leadership behavior, organizational climate, teacher job satisfaction

\section{INTRODUCTION}

The quality of education in Indonesia is considered by many to be still low. This can be seen from several indicators. First, graduates from schools or colleges who are not ready to enter the working world because of lack of competence. Second, the rank of Human Development Index (HDI) of Indonesia which was still low in 2005 ranked 110th under Vietnam with a rating of 108. Third, the International Educational Achievement (IEA) reported that the reading ability of Indonesian elementary students was ranked 38 out of 39 countries surveyed. Fourth, the academic quality among nations through the 2003 Program International Student Assessment (PISA) showed that from 41 countries surveyed for science, Indonesia was ranked 38th, while in Mathematics and reading ability it was ranked 39th. Fifth, the World Competitiveness Yearbook report of 2000, the competitiveness of Indonesian human resources was in position 46 of 47 countries surveyed. Sixth, the positions of universities that were considered favorites, such as the Gajah Mada University were only in the position of 77 Universities in Asia [1]. Seventh, the backwardness of the Indonesian nation in the field of Science and Technology compared with neighboring countries, such as Malaysia, Singapore and Thailand [7].

Various efforts to improve the quality has been done both at the central and regional levels, but education in our country is still not as expected. One proof of the low quality of education can be seen from the results of student learning is reflected from the acquisition of values and the percentage of graduation students who take the national exam (Ujian Nasional, UN). Conditions like this certainly raises questions for us. Are there any miscellaneous or errors in the implementation of education in schools so that the outcomes of teaching and learning process is not as expected.

The headmaster in carrying out leadership, as well as leadership in general, carries two functions, namely functions related to tasks and functions pertaining to group maintenance (Dorwin Cartwright and Alvi Zander as quoted by [5]; [10]). These two functions are called the dimensions of the initiation structure and the consideration dimension. Headmaster leadership behavior always leads to these two functions, which are task-oriented and subordinateoriented behaviors (teachers). Levels of behavior are diverse, there are headmasters who have task behavior, and high group maintenance behavior both, some are low both, and some are low on one of them only.

As is known, the role of a leader in an organization, whether private or government organizations, business or private is very large, achieved or not the purpose of an organization is strongly influenced by the ability of a leader in order to move and motivate subordinates. Therefore it is not surprising that an organization at a time to progress or setback every time there is a change of leader.

The problem that often arises is that not all teachers will be able to become a reliable class manager, this is caused by some obstacles, among others, because the education is still under graduate. Educational background generally comes from pure education not from management discipline or understand about management science but difficult to apply because of constrained self that dare not do self innovation.

In addition to managerial issues, in order to improve the quality of work, the teacher must be confronted with feelings that arise from him to the work he is engaged in. There is a sense of satisfaction and dissatisfaction with his work, this can be generated from the inner satisfaction of the implementation of his ability as a good manager and on the other side of the bias arise dissatisfaction because of his inability as a learning manager. Actually there are many things that can lead to satisfaction and dissatisfaction of a teacher to his work, it needs to do a deep research to reveal it.

The authoritative headmaster, not humanizing the teacher, when in the meeting never ask and listen to 
the opinions of teachers or other meeting participants can lead to a harmonious correlation between the headmaster with teachers and employees. Meanwhile, there is a headmaster who diligently dialogue with teachers, both in meetings and outside meetings. The headmaster does not hesitate to form a team to carry out special tasks, such as developing cooperation for teacher and employee training and networking with alumni. It illustrates the importance of the headmaster's role in establishing a conducive school environment, but also the support of teachers and employees and students.

The situation and condition of the area of Banjarmasin Selatan known to be dense may affect the task of teachers in schools. It is of course a challenge to test the headmaster's managerial skills in the Banjarmasin Selatan area to lead the human resources there to be more developed. Motivation, performance and job satisfaction of teachers can be influenced by several factors including the organizational climate. In addition, the school climate is the quality of the school environment that teachers constantly experience, influencing their behavior and based on their collective behavior.

\section{METHODS}

This research uses quantitative approach. Quantitative research is a study that focuses attention on the symptoms that have certain characteristics in human life, called variables [2]. The research instrument is a questionnaire, which measures principal leadership behaviors, organizational climate, and teacher job satisfaction. Repondent this research is teacher of elementary school teachers in Banjarmasin Selatan sub-district (SDN Kecamatan Banjarmasin Selatan). Data analysis uses correlation analysis, with the help of IBM SPSS Statistics 23 program.

\section{RESULT AND DISCUSSION}

This study is based on theories or was going to test the school climate theory and leadership behavior theory that has been developed earlier. The test was conducted at public elementary school in Banjarmasin Selatan sub-district, in relation to teacher's job satisfaction. The school climate theory that became the basis and was going to be tested in this research is the school climate theory from Hoy with the research team from Rutgers University which was developed in 1986, while the leadership behavior theory in this case the headmaster leadership that became the basis and will be tested is the theory of leadership study The Ohio State University.

Some of the findings in this study with respect to these theories are: public elementary schools in the subdistrict of Banjarmasin Selatan leadership behavior is in quadrant I only as many as 8 schools $(26.67 \%)$ this shows that the headmaster had a high task-oriented behavior and people-oriented behavior was high. Where in conducting one-way communication, preparing task plans, establishing work procedures and prioritizing the achievement of school headmasters had been very good. Besides being able to establish relationships, could be warm, and respect the members also put confidence in its members.

However, there were 11 schools whose headmaster leadership behavior is in quadrant III, where in holding one-way communication, preparing task plans, establishing work procedures, the headmaster were considered not good. As Halpin stated, quoted in [3] that leaders belonging to quadrant I are considered very effective, while those belonging to quadrant III are considered very ineffective.

In addition there were five schools whose leadership behavior is in the second quadrant, where the headmaster could establish a good relationship, could be warm, respect and trust in their members, but still lacking in one-way communication, preparing task plans, establishing working procedures and prioritize the achievement of results. The other six schools were in the IV quadrant which has good ability to communicate one direction, develop task plans, and establish work procedures, but was unable to establish relationships, be warm, respect and trust members.

Several other findings in this study relate to existing theories: public elementary schools in Banjarmasin Selatan sub-districts that had school climate mostly had open climate, it shows that headmasters had high support as well as teachers in one side have a high collegial and intimate too. In addition, the headmaster could suppress the lowest possible directive and restrictive, and low teacher disengagement behavior. Some things must be maintained if the headmaster and teachers need to improve, for example the school headmaster in listening and open to the input of the teachers, because according to Hoyle as quoted [8] stated to create a positive school climate, the headmaster needs to involve the whole school community.

In Banjarmasin Selatan sub-district there were still closed schools, in addition to schools of type engaged and disengaged. This situation is in accordance with the opinion of Hoy and Miskel [5], and Sergiovanni [9] that the school has certain characteristics that distinguish it from other schools. Closed school climate (closed) can be improved towards an open climate, where supportive headmasters, collegials and intimate from lower teachers are upgraded to higher levels. In contrast the directive and restriction of the headmaster as well as the disengagement of teachers who are still high are kept as low as possible.

For example, in one school that has a closed climate (closed) of 5 teachers, 2 teachers say the headmaster never gave praise sincerely and 2 teachers said the headmaster rarely gave it while another teacher stated the headmaster only occasionally Only. It must be admitted that the headmaster in giving praise to the teachers should not just plain talk, although not accompanied by the material only by giving sincere praise to the teachers also can make the best school climate. This is in line with what Kutherford expressed in Moedjiarto [8], which is less effective headmaster is more static, does not provide challenges, in addition to the field of teaching, teachers are burdened with administrative work and without appreciation. 
Most of the elementary school teachers in Banjarmasin Selatan sub-district had a high level of job satisfaction. This is a good discovery that needs to be maintained because the level of job satisfaction can affect performance. As revealed by Kreitner and Kinicki [6] that job satisfaction is a reaction to a person's emotional attitude towards his work. In this study there is evidence of a significant relationship between headmaster leadership behavior and organizational climate on teacher job satisfaction. This finding does not contradict what was written by Qazwini [11] that climate can affect job satisfaction, which refers to Herzberg's statement which states that there are two factors that affect one's job satisfaction in the organization: the motivator factors and the hygiene factors.

There is a positive and significant correlation between headmaster leadership behavior and job satisfaction of teacher of Public elementary school in Banjarmasin Selatan Subdistrict. Where the positive relationship is expressed with the value of $r=0.495$. There is a positive and significant relationship between school organizational climate and job satisfaction of elementary school teachers in Banjarmasin Selatan Subdistrict. Where this positive relationship is expressed with the value of $r=0.581$. There is a positive and significant correlation between headmaster leadership behavior and organizational climate with job satisfaction of Public elementary school teacher in Banjarmasin Selatan sub-district. Expressed by value $\mathrm{R}=0.675$.

The evidence that leadership behaviors and organizational climate relate to job satisfaction is the number Fcount with Ftable can know that the Fcount is bigger than Ftable $(11.309>3.328)$, thus it is proven that all independent variables are Leadership Classification (X1) and Climate Type School (X2) simultaneously give a significant influence on Job Satisfaction (Y). It is also seen based on the sig value. $\mathrm{F}$ of 0.000 is well below $0.05(0.000<0.05)$. As stated by Hamidah [4] that job satisfaction is a psychological, physiological and environmental aspect that causes a person to express satisfaction with the work or in other words as an attitude resulting from the balance and summation of various factors in the form of a preferred experience or a Disliked in relation to the work performed. According to Gorton quoted sulaiman quoted Hamidah [4] that satisfaction in the context of teaching refers to the level of personal and professional needs of a person in his role as a teacher.

\section{CONCLUSION AND SUGGESTIONS}

Based on the results of research then it can be concluded as follows: (1) there is a positive and significant relationship between the leadership behaviors of school headmasters with the satisfaction of teachers of Public elementary school in Banjarmasin Selatan sub-district. Where the positive relationship is expressed with the value of $\mathrm{r}=0.495$; (2) there is a positive and significant relationship between school organizational climate and job satisfaction of teachers of Public elementary school in Banjarmasin Selatan Subdistrict. Where this positive relationship is expressed with the value of $r=0.581$; and (3) there is a positive and significant relationship together between the leadership behavior of the school headmaster and the organizational climate with the satisfaction of teachers of Public elementary school in Banjarmasin Selatan sub-district. Expressed with the value of $\mathrm{R}=$ 0.675 .

Based on the results of this study, it is suggested to the headmaster to always improve his ability in preparing task plans and establishing work procedures but also can establish rapport, be warm and appreciate and trust the members. Thus the headmaster is expected to create a good school climate such as communication, planning, working procedures, and achievement of good results. For educational institutions in the district of Banjarmasin Selatanin order to develop the ability of songs through training and improve the strata of education to a professional level, so as to provide quality graduate products. For future researchers in this field to conduct similar research on different objects with other variables that may affect teacher work satisfaction.

\section{REFERENCES}

[1] Asiaweek. 2000. Ranking University. http://edition.cnn.com/ASIANOW/asiaweek/archive/.

[2] Gunawan, I. 2015. Metode Penelitian Kuantitatif. Retrieved May 25, 2016, from http://fip.um.ac.id/wpcontent/uploads/2015/12/2_Metpen-Kuantitatif.pdf.

[3] Hafiz, A. 2005. Hubungan Perilaku Kepemimpinan Kepala Sekolah dengan Mutu Lulusan pada SMP Negeri se Kota Banjarmasin. Thesis. Banjarmasin: Lambung Mangkurat University.

[4] Hamidah, N. 2009. Hubungan Manajerial Kepala Sekolah dan Komunikasi terhadap Kepuasan Kerja Guru TK di Kabupaten Balangan. Thesis. Banjarmasin: Lambung Mangkurat University.

[5] Hoy, W. K., and Miskel, C. G. 1987. Educational Administration: Theory, Research and Practice. New York: Random House.

[6] Kreitner, R., and Kinicki, A. 1989. Organizational Behavior. New York: Pearson.

[7] Kunandar. 2007. Guru Profesional, Implementasi KTSP dan Persiapan Menghadapi Sertifikasi Guru. Jakarta: PT Grafindo Persada.

[8] Moedjiarto, F. G. 2002. Fungsi Manajemen Pendidikan dalam Mengelola Pendidikan di Daerah Otonom. Jakarta: Jakarta: Bumi Aksara.

[9] Sergiovanni, T. J. 1991. Supervision: Human Perspective. New York: McGrow- Hill Book Company.

[10] Solomon, M. R. 1992. Consumer Behavior. Boston: Allyn and Bacon.

[11] Qazwini, A. K. 2008. Kepemimpinan Kepala Sekolah, Iklim Organisasi, dan Kepuasan Kerja. Banjarmasin: Lambung Mangkurat University. 